REFERENCES

Graham, C. B., Thal, A., and Wassum, C. S. (1970). Rubella-like bone changes in congenital cytomegalic inclusion disease. Radiology, 94, 39.

Merton, D. F., and Gooding, C. A. (1970). Skeletal manifestations of congenital cytomegalic inclusion disease. Radiology, 95, 333.

Singleton, E. B., Rudolph, A. J., Rosenberg, H. S, and Singer, D. B. (1966). The roentgenographic manifestations of the rubella syndrome in newborn infants. American fournal of Roensenology, 97, 82 .

A. E. McCandless, ${ }^{\star}$ C. Davis, and E. G. Hall Alder Hey Children's Hospital, Eaton Road, Liverpool L12 2AP

^Correspondence to Dr. A. E. McCandless.

\section{Coexistent coeliac disease, diabetes mellitus, and hyperthyroidism}

About one in a thousand schoolchildren in Great Britain have diabetes mellitus. Coeliac disease and thyrotoxicosis are less common. The child described below had all three, the first time that such a combination has been reported in childhood.

\section{Case report}

A girl was born in July 1959. Until the age of 6 years she was well. At this time she began to get frequent bouts of abdominal pain and loose stools. Investigations showed an iron deficiency anaemia. This was treated with oral iron but the response was poor.

When 12 she complained of irritability, weight loss, polyuria, and polydipsia. Diabetes was diagnosed and confirmed biochemically. At this time, her refractory anaemia was investigated with the following results: $\mathrm{Hb} 11 \mathrm{~g} / \mathrm{dl}$; serum iron $51 \mu \mathrm{g} / 100 \mathrm{ml}$; serum folate 0.8 $\mathrm{ng} / \mathrm{ml}$; faecal fat excretion $8 \cdot 25 \mathrm{~g} / 24 \mathrm{~h}$; blood xylose levels after $9.69 \mathrm{~g}$ xylose orally: $30 \mathrm{~min} 8.5 \mu \mathrm{g} / 100 \mathrm{ml}$, 1 hour $17 \mu \mathrm{g} / 100 \mathrm{ml}$; reticulin and thyroid antibody titres, negative; bone age 8 years 6 months (chronological age 12 years). The jejunal biopsy appearance (Fig. 1a) was that of subtotal villous atrophy. Intestinal malabsorption due to coeliac disease seemed to be the most likely cause of her long-standing symptoms.

For one year subsequently she thrived on a glutenfree, carbohydrate controlled diet with vitamin supplements. The diabetes was controlled with daily injections of lente insulin. Her weight gain velocity increased as shown in Fig. 2.

Early in 1973 she noticed that her stool frequency was increasing, and that she was experiencing abdominal pain unlike that which occurred when she ate glutencontaining foods. The rate of her weight gain diminished, and on direct questioning she admitted to heat intolerance, lassitude, and a voracious appetite. Physical examination showed a diffuse goitre over which a bruit could be heard. She had a tachycardia that per-

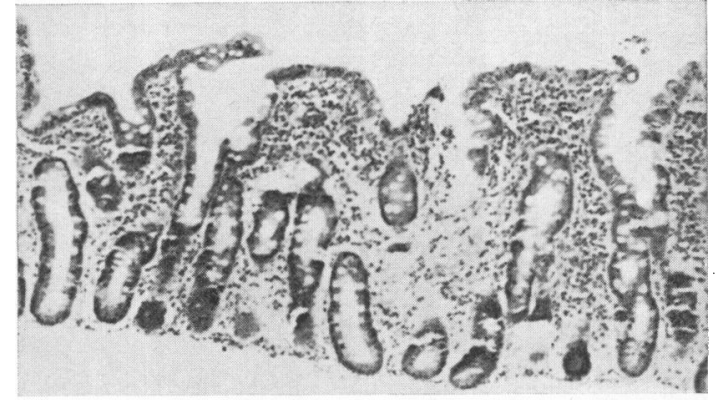

(a)

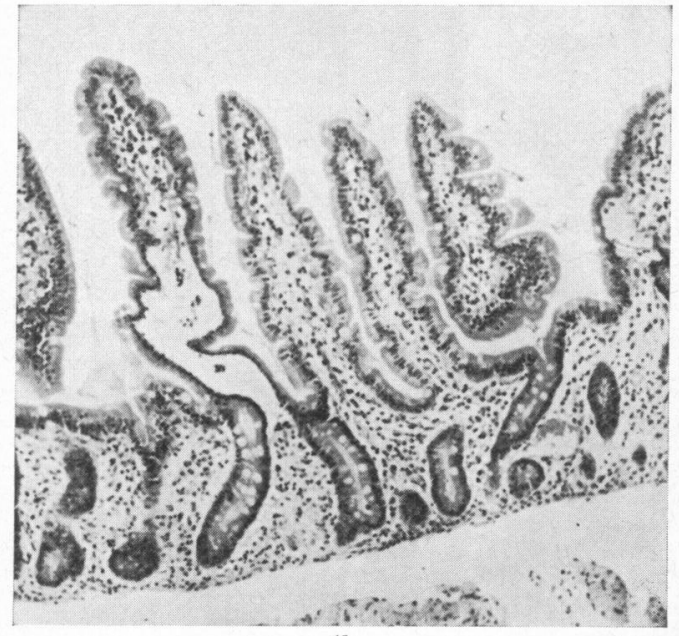

(b)

Fig. 1.-Jeiunal biopsy (a) at age 12 years, showing subtotal villous atrophy, $(b)$ at age 14 years, showing normal appearance.

sisted during sleep, moist palms, and a fine tremor. There was neither exophthalmos nor lid lag, nor signs of diabetic retinopathy or neuropathy. Investigations confirmed the clinical diagnosis of thyrotoxicosis: serum $\mathrm{T}_{4} 15.9 \mu \mathrm{g} / 100 \mathrm{ml}$, PBI $13.8 \mu \mathrm{g} / 100 \mathrm{ml}, \mathrm{T}_{3}$ uptake $60 \%$. Thyroid antibodies: thyroglobulin 1:100; microsomes, strongly positive IgG.

At this point it was discovered that her paternal uncle and grandfather both had thyrotoxicosis. Features of the uncle's condition included a high titre of circulating thyroid antibodies and poor control using drug therapy. He was eventually operated on. The grandfather responded well to drug treatment.

The present child was treated with carbimazole. The first sign of response was a decline in the insulin requirements for diabetic control. At this time, her intestinal function was reinvestigated with the following results: $\mathrm{Hb} 13.4 \mathrm{~g} / \mathrm{dl}$; blood xylose levels after $12.4 \mathrm{~g}$ xylose orally: $30 \mathrm{~min} 37 \mu \mathrm{g} / 100 \mathrm{ml}, 1$ hour $47 \mu \mathrm{g} / 100 \mathrm{ml}$; faecal fat excretion $7.05 \mathrm{~g} / 24 \mathrm{~h}$; sweat test normal; jejunal amylase and lipase activity normal; stool tryptic activity 


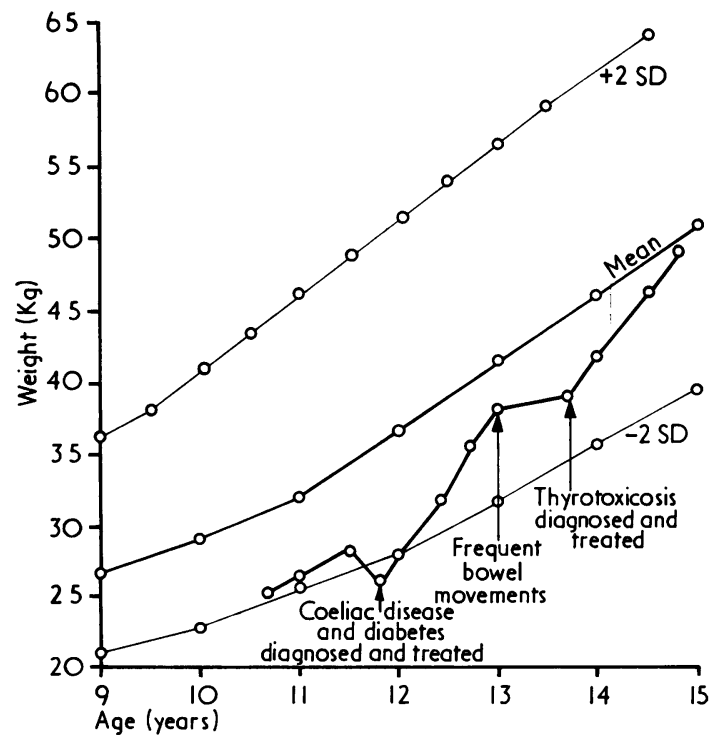

FIG. 2.-Weight chart.

$1: 1600$; bone age 12 years (chronological age 13 years 10 months); immunoglobulins, slightly raised IgM; jejunal biopsy, normal mucosa (Fig. 1b).

On review, one month after starting carbimazole, she reported normal bowel function and no abdominal pain. Her diabetic status was satisfactory, and weight gain improving.

\section{Discussion}

Undoubtedly, this girl had diabetes mellitus and subsequently developed thyrotoxicosis. The diagnosis of coeliac disease cannot be regarded as unequivocal since recurrence of subtotal villous atrophy on gluten challenge has not been shown, but we consider that the clinical progress in this case leaves little real doubt as to the diagnosis.

Hyperthyroidism complicating diabetes has been reported in adults, but there is controversy about whether this occurrence is more than would be expected by chance. In childhood, however, thyrotoxicosis has been reported to occur in $4 \%$ of diabetics (Hayles et al., 1959). Thyroxine certainly influences carbohydrate metabolism and thyroid overactivity increases intestinal glucose absorption and its subsequent oxidation and utilization (Althausen and Stockholm, 1938). This would account for the deterioration in the diabetic control of the present patient and its subsequent improvement concurrent with antithyroid therapy.

Bowel upsets do occur in thyrotoxicosis: passage of frequent loose stools is a common symptom. More detailed investigations do not appear to have been performed on children. Adult women with toxic nodular goitres have been shown to have biochemical abnormalities consistent with a malabsorptive state but normal jejunal mucosal patterns on biopsy. These changes disappeared when antithyroid treatment was established (Siurala, Julkunen, and Lamberg, 1966). It is interesting that the first symptoms of the thyrotoxicosis experienced by the present patient were gastrointestinal and were different in quality from those caused by exposure to gluten.

Diarrhoea and malabsorption may complicate diabetes mellitus. They usually occur in longstanding diabetics in association with peripheral neuropathy and are uncommon in children. Juvenile diabetics may develop steatorrhoea when control is poor, but this is reversible with improved management (Pond, 1971). This might explain the finding of high faecal fat excretion when this patient had thyrotoxicosis. Diabetes associated with coeliac disease is a less common situation (Walker-Smith and Grigor, 1969), and one for which no satisfactory explanation has yet been proposed.

All three conditions described have been separately considered as having an immunological abnormality in their pathogenesis. A common histological feature of coeliac disease and autoimmune thyroiditis is lymphocytic infiltration: this has also been found in the pancreatic islets of some diabetics (Warren, LeCompte, and Legg, 1952). Abnormal autoantibody production occurs in thyroditis, and may have a familial tendency (Anderson et al., 1964). Similarly, antibodies to insulin and pancreatic cells have been sought in diabetics. Significant results have not been obtained, although one study did show a greater incidence of thyroid antibodies in diabetic children than in normal controls (Landing et al., 1963). Coeliac patients produce antibodies to a variety of dietary proteins, but these are considered to be secondary to mucosal injury rather than a primary event. At present, therefore, there is a lack of firm evidence implicating a common autoimmune mechanism in this girl's condition.

\section{Summary}

A child with coeliac disease, diabetes mellitus, and hyperthyroidism is described. Known associations between the conditions are reviewed and evidence for a common aetiology discussed.

I am grateful to Dr. H. M. T. Coles for allowing me to report a patient in his care. Dr L. Crome kindly supplied the photographs. 
REFERENCES

Althausen, T. L., and Stockholm, M. (1938). Influence of the thyroid gland on absorption in the digestive tract. American Fournal of Physiology, 123, 577.

Anderson, J. R., Gray, K. G., Middleton, D. G., and Young, J. A. (1964). Autoimmunity and thyrotoxicosis. British Medical Fournal, 2, 1630.

Hayles, A. B., Kennedy, R. L. J., Beahrs. O. H., and Woolner, L. B. (1959). Exophthalmic goiter in children. Fournal of Clinical Endocrinology and Metabolism, 19, 138.

Landing, B. H., Pettit, M. D., Wiens, R. L., Knowles, H., and Guest, G. M. (1963). Antithyroid antibody and chronic thyroiditis in diabetes. Fournal of Clinical Endocrinology and Metabolism, 23, 119.

Pond, H. (1971). Diabetes mellitus. In Recent Advances in Paediatrics, 4th ed., p. 347. Ed. by D. Gairdner and D. Hull. Churchill, London.
Siurala, M., Julkunen, H., and Lamberg, B. A. (1966). Gastrointestinal tract in hyperthyroidism before and after treatment. Scandinavian fournal of Gastroenterology, 1, 79.

Walker-Smith, J. A., and Grigor, W. (1969). Coeliac disease in a diabetic child. Lancet, $1,1021$.

Warren, S., LeCompte, P. M., and Legg, M. A. (1966). The Pathology of Diabetes Mellitus, 4th ed., p. 69. Kimpton, London.

Timothy L. Chambers ${ }^{\star}$

Queen Mary's Hospital for Children, Carshalton, Surrey.

^Correspondence to Dr. T. L. Chambers, Department of Paediatrics and Child Health, Medical Education Centre, Seacroft Hospital, York Road, Leeds LS14 6UH.

\section{Referees 1974}

The Editors are glad to thank the following who have acted as referees during the past year, as this is the only opportunity the Editors have to acknowledge the major part our referees play in maintaining the standards of the Archives.

Charlotte M. Anderson
Barbara Ansell
J. Apley
D. Barltrop
T. M. Barratt
D. C. J. Bassett
Jane V. Bond
P. T. Bray
Sarah E. Bundey
A. H. Cameron
C. O. Carter
D. A. Chamberlain
C. Chantler
A. Claireaux
Barbara E. Clayton
F. Cockburn
Pamela A. Davies
R. H. Dowling
V. Dubowitz
J. A. Dudgeon
P. M. Dunn
J. L. Emery
J. W. Farquhar
A. Fosbrooke
P. S. Gardner
S. Godfrey
G. R. Graham
D. G. Grant

Charlotte M. Anderson

J. Apley

D. Barltrop

T. M. Barratt

D. C. J. Bassett

P. T. Bray

Sarah E. Bundey

C. O. Carter

D. A. Chamberlain

Barbara E. Clayton

R. H. Dowling

V. Dubowitz

. Dudgeon

J. W. Farquhar

A. Fosbrooke

P. S. Gardner

G. R. Graham

D. G. Grant
W. Hamilton
R. M. Hardisty
J. T. Harries
R. G. Hendrickse
E. N. Hey
A. V. Hofbrand
F. P. Hudson
J. Hunter
J. H. Hutchison
R. H. Jackson
R. S. Jones
G. F. Joplin
E. G. Knox
G. M. Komrower
P. J. Lachmann
B. M. Laurence
D. Lawson
B. Levin
B. S. Lindblad
J. G. Lines
June K. Lloyd
R. A. McCance
M. B. Mearns
F. J. W. Miller
I. H. Mills
R. D. G. Milner
D. Morley
A. P. Mowat

G. A. Neligan

B. Neville

P. E. Polani

M. J. Purves

D. N. Raine

D. H. S. Reid

Lynne M. Reid

E. O. R. Reynolds

N. R. C. Roberton

K. B. Rogers

A. Rook

Olive Scott

J. C. L. Shaw

E. A. Shinebourne

J. F. Soothill

T. C. B. Stamp

L. S. Taitz

J. M. Tanner

H. K. A. Visser

J. A. Walker-Smith

B. A. Wharton

R. H. R. White

J. S. Wigglesworth

M. L. N. Willoughby

J. Wilson

O. H. Wolff

B. S. B. Wood

C. B. S. Wood 